$$
\begin{array}{ll}
P_{s} & =\text { system pressure } \\
P_{\infty} & =\text { atmospheric pressure } \\
\text { sub } & =\text { subcooled boiling } \\
\text { sub }=0 & =\text { saturated boiling } \\
\text { sub }=85 & =\text { subcooling } 85^{\circ} \mathrm{C}
\end{array}
$$

〈Superscripts〉

$$
\begin{array}{ll}
* & =\text { the first transient region } \\
* * & =\text { the second transient region }
\end{array}
$$

\section{Literature Cited}

1) Gunther, F. C. and F. Kreith: Heat Transfer and Fluid Mechanics Institute, 113 (1949).

2) Ishigai, S. and M. Mizuno: Kikai Gakkai, 740-16, 139 (1974).
3) Katsumata, I. and M. Hirata: Trans. JSME, 43-375, 4257 (1977).

4) Katto, Y. and M. Kunihiro: Bull. JSME, 16, 1357 (1973).

5) Kutateladze, S. S.: Izy. Akad. Nauk. SSSR, 4, 529 (1951).

6) Miyasaka, Y. and S. Inada: J. Chem. Eng. Japan, 13, 22 (1980).

7) Monde, M. and Y. Katto: Trans. JSME, 43-373, 3399 (1977).

8) Monde, M. and Y. Katto: ibid., 43-373, 3408 (1977).

9) Nishikawa, $\mathrm{K}$. and $\mathrm{K}$. Yamagata: Int. J. Heat Mass Transfer, 1, 219 (1960).

10) Zuber, N.: Trans. ASME, 80-3, 711 (1958).

(Presented at the 12th Annual Symposium of Heat Transfer Soc. of Japan, at Fukuoka, 1975.)

\title{
MECHANISM OF CHLORIDE ION TRANSPORT THROUGH DIAPHRAGM-TYPE LIQUID MEMBRANE
}

\author{
TAKESHI KATAOKA, TADAAKI NISHIKI, \\ Yoshio TAMURA AND KoRETSUNE UEYAMA \\ Department of Chemical Engineering, \\ University of Osaka Prefecture, Sakai 591
}

\begin{abstract}
The permeation mechanism has been studied to obtain fundamental information for developing liquid membrane process. Chloride ion was concentrated across a diaphragm-type liquid membrane impregnated with Amberlite LA-II as a mobile carrier. This process is considered to constitute a kind of active transport process.

The permeation rates of chloride ion are explained approximately by a permeation model in which hydrochloric acid reacts with the carrier at the interface of one side of the membrane and the complex formed by the reaction then diffuses through the membrane and further reacts with sodium hydroxide in the vicinity of the opposite interface.
\end{abstract}

\section{Introduction}

Liquid membrane separations have been recently noted as a novel technique which can selectively separate and concentrate specific solutes and ions. Liquid surfactant membranes have been used for separation of hydrocarbon mixtures and for waste water treatment, especially for recovery of heavy metal ions. In basic research concerning their applications, Cussler et al. ${ }^{1,3,4,6\rangle}$ have studied separation. and concentration of several ions by using a thin microporous membrane containing mobile carriers within its pores. However, the mechanism of permeation through such a membrane has not been sufficiently

Received January 29,1979. Correspondence concerning this article should be addressed to T. Nishiki. Y. Tamura is with Hitachi Shipbuid. \& Eng. Co., Ltd., Osaka 554 examined and further investigations are needed.

In this work, the concentration of chloride ion was studied to clarify the permeation mechanism, serving as fundamental information on the liquid membrane process. The permeation rate of chloride ion was measured through a diaphragm-type liquid membrane impregnated with Amberlite LA-II as a mobile carrier, from an aqueous hydrochloric acid solution to a mixed aqueous solution of sodium chloride and sodium hydroxide. The experimental results were compared with a transport model for concentrating chloride ion across the membrane.

\section{Theory}

1.1 Model for concentration of chloride ion

When chloride ions are concentrated across a liquid membrane containing a mobile carrier, the 

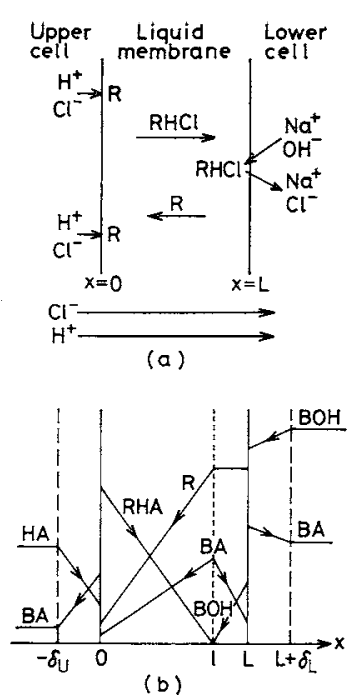

Fig. 1 Schematic diagrams of permeation model (a) and concentration profile (b)

permeation mechanism is shown schematically in Fig. 1 (a). The carrier is a water-immiscible high molecular weight amine, Amberlite LA-II ( $n$-lauryltrialkylmethylamine). At the upper interface $x=0$, hydrochloric acid reacts instantaneously with the carrier $\mathrm{R}$. The complex $\mathrm{RHCl}$ formed by the reaction diffuses across the membrane toward the lower interface $x=L$. In this region, the complex reacts with sodium hydroxide and then liberates chloride ion in the lower cell. This step regenerates the carrier $\mathrm{R}$ which then diffuses back to the upper side of the membrane and reacts again with hydrochloric acid in the upper cell. As a result of such movement of the carrier across the membrane, chloride ions are pumped from the upper to the lower cell and are concentrated in the lower cell.

\subsection{Equations of transfer rate across liquid membrane}

Figure 1 (b) shows the schematic concentration profile of diffusing species. $\mathrm{HA}, \mathrm{BOH}, \mathrm{BA}$ and RHA represent $\mathrm{HCl}, \mathrm{NaOH}, \mathrm{NaCl}$ and $\mathrm{RHCl}$, respectively. $l$ is the reaction plane where the complex RHA reacts with BOH. The position of the plane moves toward $x=0$ with the passage of time, because of the penetration of $\mathrm{NaOH}$ into the liquid membrane.

When diffusions of chemical species through the membrane are so slow that the quasi-steady state may be assumed, the fluxes of $\mathrm{H}^{+}$and $\mathrm{Cl}^{-}$(A ion) across the membrane are respectively given by

$$
\begin{aligned}
J_{\mathrm{H}} & =J_{\mathrm{HA}}=\left(D_{\mathrm{HA}} / \delta_{\mathrm{JU}}\right)\left(C_{\mathrm{HA}}^{\mathrm{U}}-C_{\mathrm{HA}}^{0}\right) \\
& =\bar{J}_{\mathrm{RHA}}=\left(\bar{D}_{\mathrm{RHA}} / \tau l\right) \bar{C}_{\mathrm{RHA}}^{0} \\
J_{\mathrm{A}} & =\bar{J}_{\mathrm{RHA}}+\bar{J}_{\mathrm{BA}}^{0} \\
& =\left(\bar{D}_{\mathrm{RHA}} / \tau l\right) \bar{C}_{\mathrm{RHA}}^{0}-\left(\bar{D}_{\mathrm{BA}} / \tau l\right)\left(\bar{C}_{\mathrm{BA}}^{1}-\bar{C}_{\mathrm{BA}}^{0}\right)
\end{aligned}
$$

where $\tau$ is a constant factor which allows for the diffusions of species through the tortuous pore within the membrane, the upper bar refers to the membrane phase, and 0 and $\mathrm{U}$ represent the upper interface $x=0$ and the upper cell compartment, respectively.

From the following equation, obtained from the condition that the flux of RHA equals in magnitude that of $\mathrm{BOH}$ in the membrane,

$$
\begin{aligned}
\bar{J}_{\mathrm{RHA}} & =\left(\bar{D}_{\mathrm{RHA}} / \tau l\right) \bar{C}_{\mathrm{RHA}}^{0}=-\bar{J}_{\mathrm{BOH}} \\
& =\left\{\bar{D}_{\mathrm{BOH}} / \tau(L-l)\right\} \bar{C}_{\mathrm{BOH}}^{\mathrm{L}}
\end{aligned}
$$

the reaction plane $l$ is expressed as

$$
l=L /\left\{1+\left(\bar{D}_{\mathrm{BOH}} \bar{C}_{\mathrm{BOH}}^{\mathrm{L}} / \bar{D}_{\mathrm{RHA}} \bar{C}_{\mathrm{RHA}}^{\mathrm{A}}\right)\right\}
$$

Here, $L$ is the thickness of the membrane and superscript $L$ refers to the lower interface $x=L$.

Since the species BA diffuses from the reaction plane $l$ to both interfaces, the flux of RHA is the sum of the two fluxes, i. e.,

$$
\begin{aligned}
\bar{J}_{\mathrm{RHA}}= & -\bar{J}_{\mathrm{BA}}^{0}+\bar{J}_{\mathrm{BA}}^{\mathrm{L}} \\
= & \left(\bar{D}_{\mathrm{BA}} / \tau l\right)\left(\bar{C}_{\mathrm{BA}}^{1}-\bar{C}_{\mathrm{BA}}^{0}\right) \\
& +\left\{\bar{D}_{\mathrm{BA}} / \tau(L-l)\right\}\left(\bar{C}_{\mathrm{BA}}^{1}-\bar{C}_{\mathrm{BA}_{A}}^{\mathrm{L}}\right)
\end{aligned}
$$

When Eq. (4) is substituted into Eq. (5), the concentration of $\mathrm{BA}$ at $x=l$ is given by

$$
\begin{aligned}
\bar{C}_{\mathrm{BA}}^{\mathrm{I}}= & \left\{\left(\bar{D}_{\mathrm{RHA}} / \bar{D}_{\mathrm{BA}}\right) \bar{C}_{\mathrm{RHA}}^{0}+\bar{C}_{\mathrm{BA}}^{0}\right. \\
& \left.+\left(\bar{D}_{\mathrm{RHA}} \bar{C}_{\mathrm{RHA}}^{0} / \bar{D}_{\mathrm{BOH}} \bar{C}_{\mathrm{BOH}}^{\mathrm{L}}\right) \bar{C}_{\mathrm{BA}}^{\mathrm{L}}\right\} / \\
& \left\{1+\left(\bar{D}_{\mathrm{RHA}} \bar{C}_{\mathrm{RHA}}^{0} / \bar{D}_{\mathrm{BOH}} \bar{C}_{\mathrm{BOH}}^{\mathrm{L} O H}\right)\right\}
\end{aligned}
$$

Further, by substituting Eqs. (4) and (6) into Eq. (2), the flux of A ion is finally expressed as

$$
J_{\mathrm{A}}=\left(\bar{D}_{\mathrm{RHA}} / \tau L\right) \bar{C}_{\mathrm{RHA}}^{0}-\left(\bar{D}_{\mathrm{BA}} / \tau L\right)\left(\bar{C}_{\mathrm{BA}}^{\mathrm{L}}-\bar{C}_{\mathrm{BA}}^{0}\right)
$$

The flux of $\mathrm{H}$ ion is similarly obtained.

$$
J_{\mathrm{H}}=\left(\bar{D}_{\mathrm{RHA}} / \tau L\right) \bar{C}_{\mathrm{RHA}}^{0}+\left(\bar{D}_{\mathrm{BOH}} / \tau L\right) \bar{C}_{\mathrm{BOH}}^{\mathrm{L}}
$$

$\bar{C}_{\mathrm{RHA}_{\mathrm{A}}}^{0}$ is obtained from Eq. (9) and the equilibrium relationship of extraction of hydrochloric acid by Amberlite LA-II in xylene.

$$
\begin{aligned}
& \left(D_{\mathrm{HA}} / \delta_{\mathrm{U}}\right)\left(C_{\mathrm{HA}}^{\mathrm{U}}-C_{\mathrm{HA}}^{0}\right) \\
& \quad=\left(\bar{D}_{\mathrm{RHA}} / \tau L\right) \bar{C}_{\mathrm{RHA}}^{0}+\left(\bar{D}_{\mathrm{BOH}} / \tau L\right) \bar{C}_{\mathrm{BOH}}^{\mathrm{L}}
\end{aligned}
$$

This relation is obtained by applying the condition that the flux of $\mathrm{H}^{+}$in the upper cell is equivalent to that in the membrane at the upper interface.

When the concentration of $\mathrm{NaOH}$ in the lower cell is very low, $\mathrm{NaOH}$ scarcely dissolves into the membrane phase. Therefore, $\widetilde{C}_{\mathrm{B} O H}^{\mathrm{L}}$ is substantially zero and the position of the reaction plane $l$ moves to the lower interface $x=L$. This corresponds to the case when $\mathrm{RHCl}$ reacts with $\mathrm{BOH}$ at the interface $x=L$. In this case, Eq. (8) simplifies to

$$
J_{\mathrm{H}}=\left(\vec{D}_{\mathrm{RHA}} / \tau L\right) \bar{C}_{\mathrm{RHA}}^{0}
$$

Furthermore, in the case when $\bar{C}_{\mathrm{RHA}}^{0}$ is equal to the carrier concentration $C_{\mathrm{T}}$, Eq. (10) reduces to

$$
J_{\mathrm{H}}=\left(\bar{D}_{\mathrm{RHA}} / \tau L\right) C_{\mathrm{T}}
$$

and the flux of $\mathrm{H}^{+}$increases in proportion to $C_{\mathrm{T}}$.

The concentration of ionic species $i$ in the upper cell can be calculated successively as a function of 
time by using Eq. (13), which is obtained from Eq. (12).

$$
\begin{gathered}
-V\left(d C_{\mathrm{i}}^{\mathrm{U}} / d t\right)=S J_{\mathrm{i}} \quad \mathrm{i}=\mathrm{A}, \mathrm{H} \\
\Delta C_{\mathrm{i}}^{\mathrm{U}}=(S / V) J_{\mathrm{i}} \Delta t
\end{gathered}
$$

The mass transfer coefficients $D_{\mathrm{HA}} / \delta_{\mathrm{U}}$ and $D_{\mathrm{BOH}} / \delta_{\mathrm{L}}$, which are necessary for calculation, were evaluated from the following equations*.

$$
\begin{aligned}
& S h^{\mathrm{U}}=0.158\left(S c^{\mathrm{U}}\right)^{1 / 3}\left(R e^{\mathrm{U}}\right)^{0.63} \\
& S h^{\mathrm{L}}=0.264\left(S c^{\mathrm{L}}\right)^{1 / 3}\left(R e^{\mathrm{L}}\right)^{0.53}
\end{aligned}
$$

The values of diffusivity $D_{\mathrm{HA}}$ and $D_{\mathrm{BOH}}$ were adopted to be $3.40 \times 10^{-5} \mathrm{~cm}^{2} / \mathrm{sec}^{2)}$ and $1.96 \times 10^{-5} \mathrm{~cm}^{2} / \mathrm{sec}^{5)}$, respectively.

\section{Experiments}

\section{1 Experimental apparatus}

The permeation apparatus used is illustrated in Fig. 2. The membrane was clamped between two glass half-cells with inner diameter of $10 \mathrm{~cm}$. The upper cell was fitted with four stainless-steel baffles. The turbine impeller with six flat-blades fitted at the center of liquid depth was driven with a variablespeed motor in the upper cell. The lower cell was stirred using a magnetic stirrer of $4.3 \mathrm{~cm}$ length. The apparatus was placed in an air bath which was maintained at $30^{\circ} \mathrm{C}$. In addition, all metal surfaces within the apparatus were covered with thin Teflon sheet.

\section{2 Experimental procedures}

A Tefton millipore membrane filter which had a thickness of $125 \mu \mathrm{m}$, a porosity of about $68 \%$ and a pore size of $10 \mu \mathrm{m}$ was used as a diaphragm throughout this study. The pores were filled by immersing the filter in the membrane solution. The membrane solution was prepared by dissolving Amberlite LA-II as a mobile carrier into a mixed solution of xylene and liquid paraffin, which is used to control viscosity of the solution (volume ratio of paraffin/xylene is 0 to $100 \%$ ). The aqueous solutions were prepared by saturating degassed distilled water with xylene.

While stirring at a constant speed in each side of the cell (upper: $82 \mathrm{rpm}$, lower: $360 \mathrm{rpm})^{* *}$, the mixed aqueous solution of $\mathrm{NaCl}$ and $\mathrm{NaOH}(750 \mathrm{ml})$ was poured into the lower cell as air was taken off. Aqueous $\mathrm{HCl}$ solution of the same volume and $\mathrm{Cl}^{-}$concentration was then poured along the wall of the compartment into the upper cell.

The ion concentrations on each side of the cell

* The rates of dissolution of benzoic acid from a flat surface into several liquids were measured by using the same apparatus as used in this study. Benzoic acid was cast in a circular depression of the bottom plate or the top plate. The mass transfer coefficients obtained from this experiment were correlated by Eqs. (14) and (15), respectively.

** These stirring speeds did not vibrate the membrane appreciably and allowed the concentrations of the bulk phases on each side of the cell to be uniform.

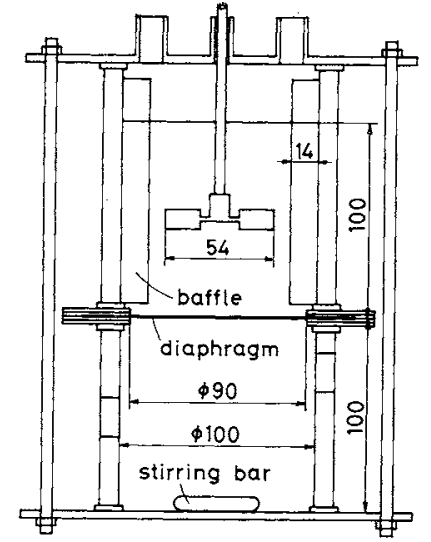

Fig. 2 Permeability cell

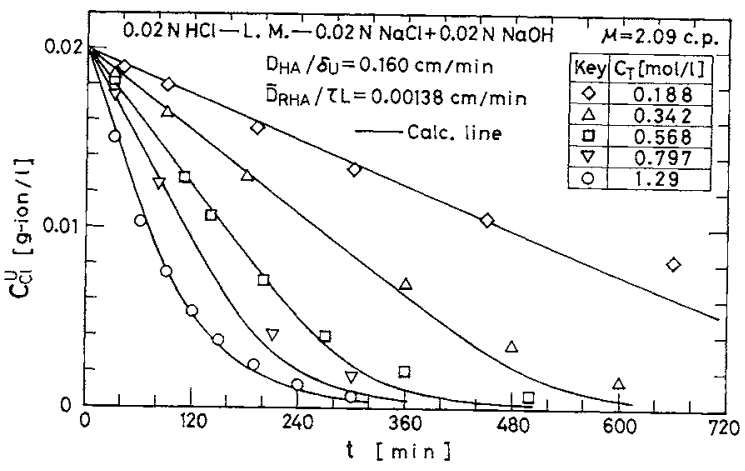

Fig. 3 Concentration of chloride ion in upper cell vs. time

were measured at regular intervals by taking samples of known volumes with a pipette and a syringe for analysis and by replacing them with fresh solutions ${ }^{\dagger}$. The $\mathrm{H}^{+}$and $\mathrm{Cl}^{-}$concentrations were determined by the neutralization titration method and the Mohr method, respectively.

Extraction equilibria of hydrochloric acid by Amberlite LA-II in xylene were measured by the batchwise method at $30^{\circ} \mathrm{C}$. The concentration of free amine was determined by titrating with methanol solution containing hydrochloric acid using bromocresol green as an indicator.

\section{Results and Discussion}

\section{1 Effect of carrier concentration}

Viscosity of liquid membrane solution was kept constant at 2.09 c.p., and the permeation rates of $\mathrm{H}^{+}$ and $\mathrm{Cl}^{-}$were measured by varying the carrier concentration from $0.188 \mathrm{M}$ to $1.29 \mathrm{M}$ for the system of $0.02 \mathrm{M} \mathrm{HCl}$-liquid membrane- $(0.02 \mathrm{M} \mathrm{NaCl}+$ $0.02 \mathrm{M} \mathrm{NaOH}$ ).

The variation of $\mathrm{Cl}^{-}$concentration in the upper cell with time is shown in Fig. 3. The change of $\mathrm{H}^{+}$ concentration (not shown in the figure) almost agrees

$t$ The change in concentration by this sampling might be neglected, since the volume $\left(5 \mathrm{~cm}^{3}\right.$ for each sampling) was adequately small compared with the total volume. 


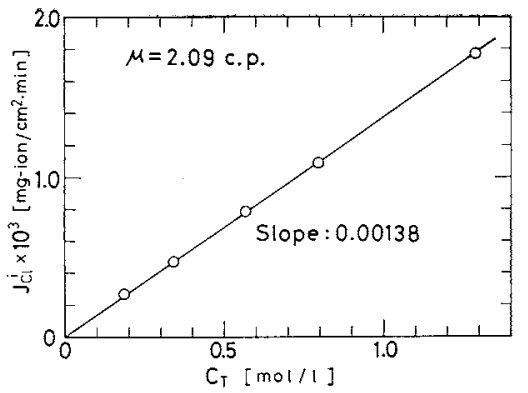

Fig. 4 Effect of carrier concentration on initial flux of chloride ion

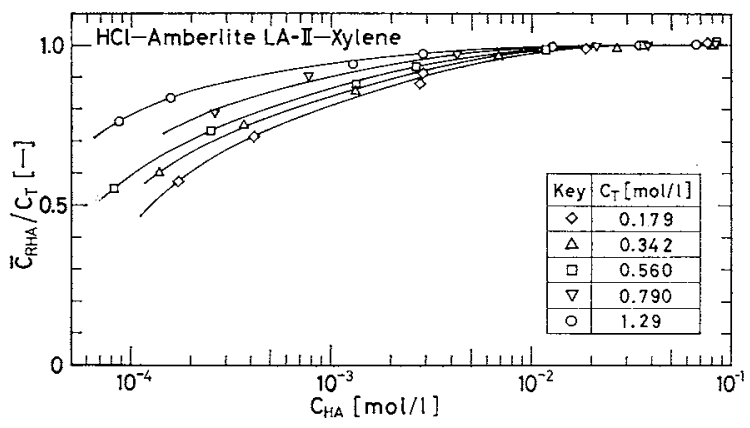

Fig. 5 Extraction equilibrium of hydrochloric acid by Amberlite LA-II in xylene

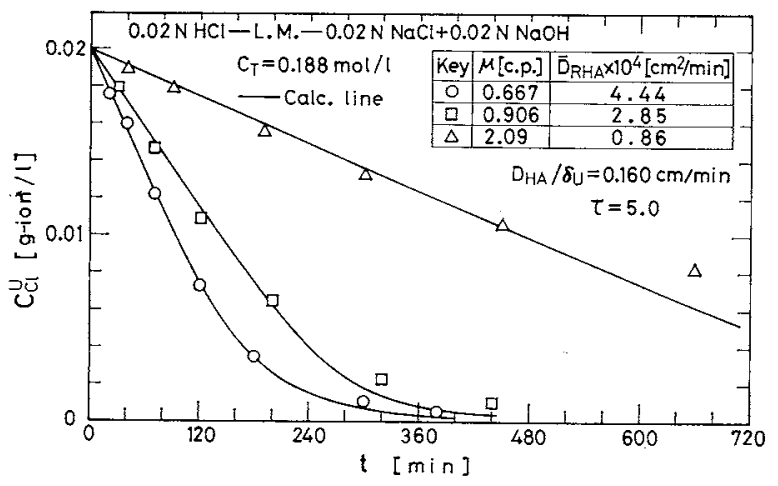

Fig. 6 Concentration of chloride ion in upper cell ys. time

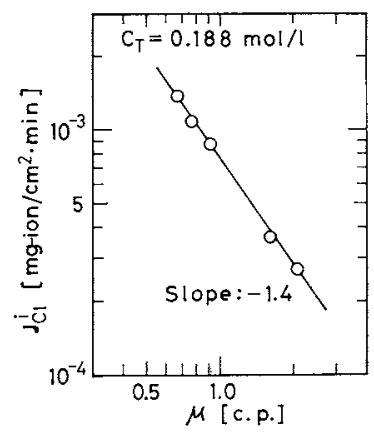

Fig. 7 Effect of viscosity of liquid membrane solution on initial flux of chloride ion

with that for $\mathrm{Cl}^{-}$. This result shows that sodium chloride and sodium hydroxide do not permeate appreciably through the membrane, since concentrations of both in the cell solution are low. The $\mathrm{Cl}^{-}$ concentration initially decreases linearly with time and then gradually becomes concave upward.

The effect of the carrier concentration $C_{\mathrm{T}}$ on the initial flux of $\mathrm{Cl}^{-}$, which was obtained from the slope of each straight line near the time zero in Fig. 3, is shown in Fig. 4. The flux increases in proportion to $C_{\mathrm{T}}$, and the slope should equal $\bar{D}_{\mathrm{RH} A} / \tau L$ of Eq. (11), that is,

$$
\bar{D}_{\mathrm{RHA}} / \tau L=0.00138
$$

Using the above relation and the equilibrium relation presented in Fig. 5, the $\mathrm{Cl}^{-}$concentration in the upper cell as a function of time calculated from Eqs. (7), (9) and (13) is also shown in Fig. 3. In this calculation, the second term on the right-hand side of Eqs. (7) and (9) were neglected, because sodium chloride and sodium hydroxide scarcely permeated, as mentioned above. The calculated values approximately agree with the experimental data over the whole experimental time.

\section{2 Effect of viscosity of impregnated solution in membrane}

Figure 6 shows the representative results where the time-dependent concentration of $\mathrm{Cl}^{-}$in the upper cell was measured for a constant carrier concentration of $0.188 \mathrm{M}$ and the viscosity of liquid membrane solution was varied from 0.667 c.p. to 2.09 c.p. In this experiment, hardly any difference in concentration between $\mathrm{Cl}^{-}$and $\mathrm{H}^{+}$is detected and the data initially decrease linearly with time in the same manner as in Fig. 3.

In Fig. 7, the initial fluxes of $\mathrm{Cl}^{-}$are plotted against the viscosity of liquid membrane solution. The result shows that there holds a linear relationship with a slope of -1.4 between the flux and the viscosity. As is expected from Eq. (11), this relation suggests the effect of viscosity on the diffusivity of $\mathrm{RHCl}$, because $C_{\mathrm{T}}$ is constant. That is, the viscosity dependence of the diffusivity may be expressed approximately by the following equation:

$$
\bar{D}_{\mathrm{RHA}} / \bar{D}_{\mathrm{RHA}, \mathrm{S}}=\left(\mu_{\mathrm{S}} / \mu\right)^{1.4}
$$

where $\bar{D}_{\mathrm{RHA}, \mathrm{S}}$ is the diffusivity of the complex $\mathrm{RHCl}$ in xylene estimated from the Wilke-Chang equation" and $\mu_{\mathrm{S}}$ is the viscosity of xylene. Although Eq. (17) shows a large effect of viscosity on diffusivity compared with the Stokes-Einstein relation and the results of Watanabe and Miyauchi ${ }^{8}$ on the diffusivity of iodine in poly(dimethylsiloxane), this is caused by the situation where the high-molecular weight substances diffuse within the solution contained in the pores ${ }^{7}$. However, it is necessary to examine this point further.

Using the diffusivity $\bar{D}_{R H A}$ evaluated from Eq. (17), the $\mathrm{Cl}^{-}$concentration calculated in the same way as in the case of Fig. 3 is also shown by solid lines in Fig. 6. The agreement between calculation and experiment for each viscosity is fairly good. Further, the 
constant factor $\tau$ of the membrane was obtained to be 5.0 by using Eq. (16) and the diffusivity $8.6 \times 10^{-5} \mathrm{~cm}^{2} /$ min at a viscosity of 2.09 c.p.

This value agrees fairly well with $\tau=4.7$ obtained from the results of Miyauchi et al. ${ }^{8}$ on the permeation rate of iodine through a porous Teflon membrane, impregnated with poly (dimethylsiloxane).

\section{3 Effect of concentration of sodium hydroxide}

To study the effect of $\mathrm{NaOH}$ concentration, experiments were conducted for $0.5 \mathrm{M} \mathrm{NaOH}$ solution in place of $0.02 \mathrm{M} \mathrm{NaOH}$ in the experimental system shown in Fig. 3. The results are presented in Fig. 8, which shows the variation of concentrations of each ion in the upper cell with time. No difference in concentration between $\mathrm{Cl}^{-}$and $\mathrm{H}^{+}$is appreciably detected initially but gradually increases with time. It may be considered that such a difference in concentration is caused by a slight permeation of $\mathrm{NaOH}$ into the membrane, since the $\mathrm{NaOH}$ concentration in the lower cell solution is large.

Figure 9 shows the results of plotting the $\mathrm{NaOH}$ concentration transferred from the lower to the upper cell against time. These results were obtained from measurement by filling the upper cell with degassed distilled water in place of aqueous hydrochloric acid solution.

As shown in the figure, the experimental data for each carrier concentration are approximated by two straight lines*, and then values of $\left(\bar{D}_{\mathrm{BOH}} / \tau L\right)(1 / m)$ are determined so that the $\mathrm{NaOH}$ concentrations calculated from the following equations may agree with the respective lines:

$$
\begin{gathered}
C_{\mathrm{BOH}}^{\mathrm{U}} / C_{\mathrm{BOH}}^{\mathrm{L}}=1-\exp \left\{-(S / V) K_{\mathrm{BOH}} t\right\} \\
\frac{1}{K_{\mathrm{BOH}}}=\frac{1}{\left(D_{\mathrm{BOH}} / \delta_{\mathrm{L}}\right)}+\frac{m}{\left(\bar{D}_{\mathrm{BOH}} / \tau L\right)}+\frac{1}{\left(D_{\mathrm{BOH}} / \delta_{\mathrm{U}}\right)}
\end{gathered}
$$

where $m$ is a distribution coefficient of $\mathrm{NaOH}$ between the aqueous and the membrane phase.

The time-dependent concentrations of $\mathrm{Cl}^{-}$and $\mathrm{H}^{+}$ were calculated from Eqs. (7), (8), (9) and (13) using the values of $\bar{D}_{\mathrm{BOH}} / \tau L m$ obtained. The values of $\bar{D}_{\mathrm{BOH}} /$ $\tau \mathrm{Lm}$ for the carrier concentrations of $0.342 \mathrm{M}$ and $0.791 \mathrm{M}$ were estimated by interpolation. In Fig. 8, the calculated values for $\mathrm{Cl}^{-}$and $\mathrm{H}^{+}$are also shown by the solid and the broken curve, respectively. The calculated values for each carrier concentration generally agree with the experimental data, although there are some deviations between the calculated value and the experimental one in the range of long experimental times.

* The data shown in Fig. 9 are reliable and reproducible ones obtained by repeating the experiment. It is not clear that $C_{\mathrm{NaOH}}^{\mathrm{U}}$ increases rapidly above $180 \mathrm{~min}$, but this phenomenon is caused by the characteristics of the liquid membrane used in this study. This point also needs to be examined further.

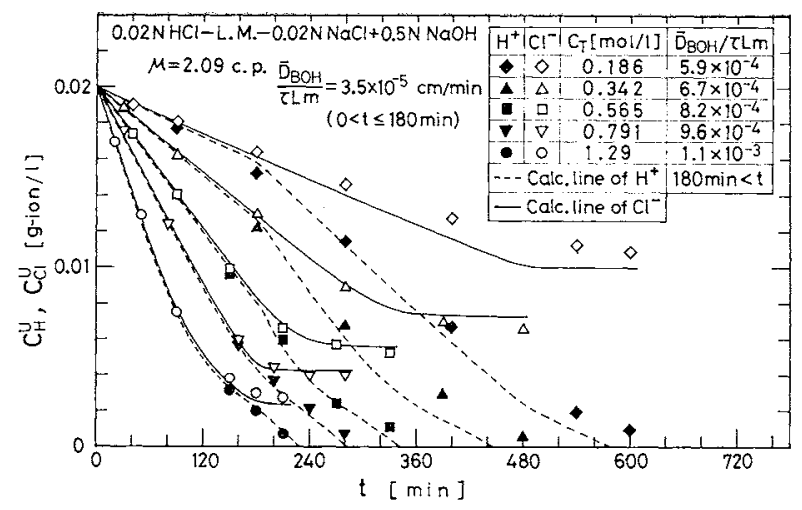

Fig. 8 Concentrations of chloride ion and hydrogen ion in upper cell vs. time

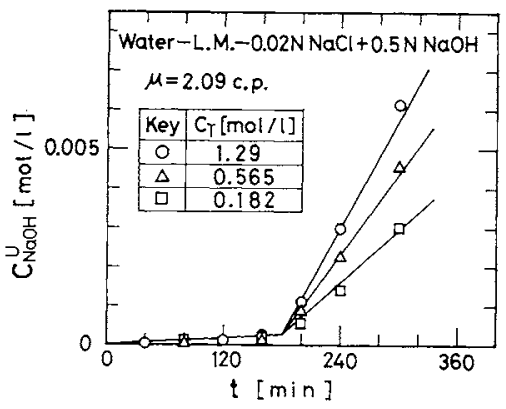

Fig. 9 Permeation rate of sodium hydroxide through membrane

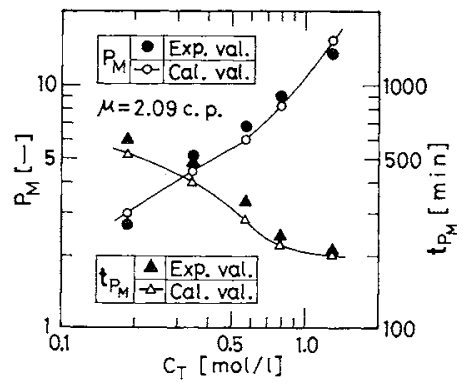

Fig. 10 Plots of $P_{M}$ and $t_{P \mathrm{M}}$ VS. $C_{\mathrm{T}}$

\section{4 Pumping of chloride ion}

Figure 10 shows the results in which the maximum pumping factor $P_{\mathrm{M}}$ and the time $t_{P_{M}}$ required to reach $P_{\mathrm{M}}$ are plotted against the carrier concentration $C_{\mathrm{T}}$ for the same system as shown in Fig. 8. $\quad P_{\mathrm{M}}$ is the ratio of $\mathrm{Cl}^{-}$concentration in the lower cell to that in the upper cell solution when the maximum concentration difference was attained across the membrane.

Agreement between experimental and calculated values is fairly good. It was found that $P_{\mathrm{M}}$ becomes large and $t_{P_{M L}}$ becomes small with increasing $C_{T}$. Since the pumping factor is also affected by the viscosity of a liquid membrane solution, it will be necessary to examine this point in further detail.

\section{Conclusion}

To clarify the mechanism of permeation through a 
liquid membrane, using a diaphragm-type liquid membrane impregnated with Amberlite LA-II as a mobile carrier, the time-dependent concentration of chloride ion was measured.

The permeation rate of chloride ion is affected by the concentration of sodium hydroxide, which permeates slightly through the membrane.

The experimental results for the permeation rates of chloride ion and hydrogen ion can be explained approximately by a permeation model in which hydrochloric acid and the carrier react at the interface of one side of the membrane and then the complex formed by the reaction reacts with sodium hydroxide in the vicinity of the opposite interface.

\section{Acknowledgment}

This work was partly supported by the Science Research Foundation of the Ministry of Education, Japan, Grant No. 355406. The authors wish to acknowledge the support leading to the publication of this article.

\section{Nomenclature}

\begin{tabular}{|c|c|c|}
\hline$C$ & $=$ concentration of chemical species & \\
\hline$C_{\mathrm{T}}$ & $=$ total concentration of mobile carrier & \\
\hline$D$ & $=$ diffusivity & {$\left[\mathrm{cm}^{2} / 1\right.$} \\
\hline $\bar{D}_{\mathrm{RHA}, \mathrm{S}}$ & $=$ diffusivity of complex $\mathrm{RHCl}$ in xylene & \\
\hline$d$ & $=$ representative length & \\
\hline$J$ & $=$ flux of chemical species & $1 / \mathrm{cm}^{2}$ \\
\hline$K_{\mathrm{BOH}}$ & $\begin{aligned}= & \text { overall mass-transfer coefficient of } \\
& \text { sodium hydroxide defined by Eq. (19) }\end{aligned}$ & \\
\hline$k$ & $=$ mass-transfer coefficient & {$[\mathrm{cm}$} \\
\hline$L$ & $=$ thickness of membrane & \\
\hline 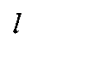 & $\begin{array}{l}=\text { distance from the upper interface to } \\
\text { the reaction plane }\end{array}$ & \\
\hline$m$ & $\begin{array}{l}=\text { distribution coefficient of sodium hydr } \\
\text { between the aqueous and the } \\
\text { membrane phases }\end{array}$ & \\
\hline$P_{\mathrm{M}}$ & $\begin{array}{l}=\text { maximum pumping factor of chloride } \\
\text { ion }\end{array}$ & \\
\hline $\operatorname{Re}$ & $=$ Reynolds number, $\omega d^{2} \rho / \mu$ & \\
\hline$S$ & $=$ area of diaphragm & \\
\hline$S c$ & $=$ Schmidt number, $\mu / \rho D$ & \\
\hline
\end{tabular}

$\begin{array}{llr}S h & =\text { Sherwood number, } k d / D & {[-]} \\ t & =\text { time } & {[\mathrm{min}]} \\ t_{P_{\mathrm{M}}} & =\text { time corresponding to } P_{\mathrm{M}} & {[\mathrm{min}]} \\ \Delta t & =\text { short time } & {[\mathrm{min}]} \\ V & =\text { volume of each cell compartment } & {\left[\mathrm{cm}^{3}\right]} \\ x & =\text { distance from the upper interface } & {[\mathrm{cm}]} \\ \delta & =\text { liquid film thickness } & \\ \mu & =\text { viscosity } & {[\mathrm{cm}]} \\ \mu_{\mathrm{S}} & =\text { viscosity of xylene } & {[\mathrm{c} \cdot \mathrm{p} .]} \\ \rho & =\text { density } & {\left[\mathrm{g} / \mathrm{cm}^{3}\right]} \\ \tau & =\text { membrane constant } & {[-]} \\ \omega & =\text { rotational speed } & {[\mathrm{rad} / \mathrm{sec}]}\end{array}$

〈Subscripts〉

$\begin{array}{ll}\mathrm{A} & =\text { chloride ion } \\ \mathrm{BA} & =\text { sodium chloride } \\ \mathrm{BOH} & =\text { sodium hydroxide } \\ \mathrm{H} & =\text { hydrogen ion } \\ \mathrm{HA} & =\text { hydrochloric acid } \\ \mathrm{i} & =\text { ionic species } \\ \mathrm{L} & =\text { lower cell } \\ \mathrm{RHA} & =\text { complex } \mathrm{RHCl} \\ \mathrm{U} & =\text { upper cell }\end{array}$

$\langle$ Superscripts〉

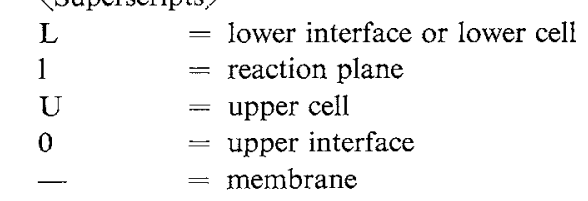

\section{Literature Cited}

1) Caracciolo, F., E. L. Cussler and D. F. Evans: AIChE J., 21, 160 (1975).

2) Chang, P. and C. R. Wilke: J. Phys. Chem., 59, 592 (1955).

3) Choy, E. M., D. F. Evans and E. L. Cussler: I. Am. Chem. Soc., 96, 7085 (1974).

4) Cussler, E. L.: AIChE J., 17, 1300 (1971).

5) "International Critical Tables", Vol. V, McGraw-Hill, New York (1933).

6) Reush, C. F. and E. L. Cussler: AIChE J., 19, 736 (1973).

7) Sherwood, T. K., R. L. Pigford and C. R. Wilke: "Mass Transfer", McGraw-Hill, New York (1975).

8) Watanabe, H. and T. Miyauchi: Kagaku Kogaku Ronbunshu, 2, 262 (1976).

9) Wilke, C. R. and P. Chang: AIChE J., 1, 264 (1955). 